\title{
Analisis Kualitas Produk dan Layanan Purnajual Terhadap Proses Keputusan Pembelian Konsumen Honda All New Vario 125 Melalui Citra Merek Sebagai Mediator
}

\author{
Edi Fitriana Afriza \\ Universitas Siliwangi \\ Email: edifitriana@unsil.ac.id
}

\begin{abstract}
Research shown to identify and analyses the associated simultaneous or partially influence of product quality and after-sales service towards the brand image, as well as its implications on product purchase decision process is All New Honda Vario 125. Survey with quantitative descriptive analysis accompanied approach is used as a method of research supported through fieldwork, research instruments questionnaires, depth-interviews, and study of the literature to obtain primary and secondary data. Simple random sampling is a sampling technique that used the techniques of the obtained sample size as much as 119 respondents continued through path analysis, t-test, F-test, and sobel test to determine the results of the research. The results of the analysis it is known that the quality of products and services Post-sale partially and simultaneous effect significant towards product brand image Honda All New Vario 125. In addition, product quality and after-sales service are partial and simultaneous have influence on product purchase decision process is All New Honda Vario 125. It is Continued by testing the sobel test of brand image which had a significant influence of decision product purchase All New Honda Vario 125. It is conducted by indirect testing from both the product quality and after-sales service to purchase decision process through the brand image.
\end{abstract}

Keywords: Decision, customer, brand image

\begin{abstract}
Abstrak
Penelitian ditunjukkan untuk mengetahui dan menganalisis terkait pengaruh secara parsial maupun simultan dari kualitas produk dan layanan purnajual terhadap citra merek, serta implikasinya pada proses keputusan pembelian produk Honda All New Vario 125. Survey dengan pendekatan kuantitatif disertai analisis deskriptif digunakan sebagai metode penelitian ditunjang melalui studi lapangan, instrument penelitian kuesioner, depth interview, dan studi pustaka untuk mendapatkan data primer serta sekunder. Simple random sampling merupakan teknik pengambilan sampel yang dipakai dari teknik tersebut diperoleh ukuran sampel sebanyak 119 responden dilanjutkan melalui path analysis, uji t, uji F, dan sobel test untuk menentukan hasil penelitian. Dari hasil analisis tersebut diketahui bahwa kualitas produk dan layanan Purnajual secara parsial dan simultan berpengaruh siginfikan terhadap citra merek produk Honda All New Vario 125. Selain itu juga kualitas produk dan layanan purnajual secara parsial dan simultan memiliki pengaruh terhadap proses keputusan pembelian produk Honda All New Vario 125. Dilanjutkan menguji sobel tes dari citra merek yang mempunyai pengaruh signifikan terhadap proses keputusan pembelian produk Honda All New Vario 125. Pengujian secara tidak langsung baik dari kualitas produk dan layanan purna jual berpengaruh terhadap proses keputusan pembelian melalui citra merek.
\end{abstract}

Kata kunci: keputusan, konsumen, citra merek.

\section{Pendahuluan}

Dewasa ini persaingan bisnis di era industri 4.0 semakin kompetitif dan memunculkan keunggulan bersaing, sehingga indonesia harus mempersiapkan diri menghadapi perubahan-perubahan besar pada berbagai sektor di bidang bisnis, To differentiate from competitors and to enhance competitive advantage, increasing numbers of companies bundle products with services (Bijvank et al., 2010; Davies, 2004; Penttinen dan Palmer, 2007). Dengan terbukanya pasar global, maka para produsen dituntut untuk melakukan pembenahan kinerjanya dalam rangka memenuhi kualitas produk atau jasa yang 
dikehendaki oleh pasar (konsumen). Industri otomotif indonesia memiliki kemajuan signifikan dikarenakan konsumen belum merasakan ketersediaan alat transportasi umum yang representatif, ditunjang dengan banyaknya bantuan keuangan secara kredit dari lembaga keuangan menjadikan pembelian kendaraan roda dua semakin mudah. Dilihat dari kacamata industri otomotif para pebisnis bersaing melalui penciptaan produk yang berkualitas dengan memiliki spesifikasi dan tampilan terlihat menarik yang bertujuan untuk memenuhi ekspektasi dari konsumen. Konsumen memiliki kebebasan dalam menentukan produk pilihannya, pilihan konsumen inilah dapat dijadikan suatu peluang bagi perusahaan untuk mendapatkan keuntungan yang optimal pada kegiatan pemasaran, oleh karena itu perusahaan harus benar-benar mengerti produk yang seperti apa yang diinginkan oleh konsumen (Kotler dan Keller, 2012). Dari pekerjannya, pemasaran bukan lagi sekedar aktivitas menemukan konsumen yang tepat untuk sebuah produk, melainkan menekankan produk yang tepat untuk konsumen. Konsumen kontemporer mulai cerdas dan selektif dalam melakukan pembelian terhadap produk maupun jasa, apalagi dengan adanya citra merk produk dan jasa yang ditawarkan perusahaan, memiliki nilai tersendiri bagi masyarakat yang menggunakannya. Kualitas produk motor Honda sudah tidak diragukan lagi, apalagi dengan berbagai jasa yang diberikan dari pihak Honda kepada konsumen, dengan adanya take and gift dari perusahaan menjadikan para konsumennya tidak berpikir panjang untuk menggunakan produk dan jasa yang ditawarkan. Memberikan produk berkualitas yang sesuai ekspektasi konsumen sangat penting untuk kesuksesan dan kelangsungan hidup di lingkungan industri otomotif yang kompetitif saat ini. The provision of products and services of high quality enhances reputation, improves customer retention, attracts new customers through word of mouth, and increases financial performance and profitability (Julian and Ramaseshan, 1994; Zeithaml, 1996).

Dengan memunculkan kualitas produk, perusahaan Honda berusaha untuk mendominasi pasar indsutri otomotif kendaraan roda dua indonesia, apalagi dengan jenis motor Honda matic yang masih dibanjiri oleh pasar konsumen indonesia. Kualitas produk Honda All New Vario 125 memberikan bukti bahwa kendaran matic yang dihasilkan Honda memiliki tempat tersendiri bagi konsumen/ pasar indonesia, ditambah lagi dengan fitur dan spesifikasi yang menarik serta memberikan daya tarik tersendiri bagi kalangan milenial. By improved vehicle quality, competition in quality is more than just the quality of the vehicle itself; it includes marketing and sales activities as well as after-sales provision of warranty and maintenance service (N.P. Archer, 1996). The basic approach for manufacturers to provide after-sales service is to anchor in manufacturing and then move downstream to distribution, operation, maintenance etc through the life cycle of the product (Davies, 2004). Layanan purna jual yang menjadi tombak utama dalam kegiatan pemasaran dimana layanan tersebut digulirkan dalam menciptakan dan meningkatkan kepercayaan konsumen terhadap perusahaan, layanan purna jual juga memberikan kesan bahwa perusahaan memiliki kepedulian dan ingin menciptakan hubungan yang harmonis antara perusahaan dengan konsumen. PT Astra Honda Motor (AHM) merupakan pelopor industri sepeda motor di indonesia. Didirikan pada 11 juni 1971 dengan nama awal PT. Federal Motor, yang sahamnya secara mayoritas dimiliki oleh PT. Astra International. Saat ini PT Astra Honda Motor di dukung oleh 1.700 showroom dealer penjualan yang diberi kode H1, 3.600 layanan service atau bengkel AHASS (Astra Honda Authorized Service Station) dengan kode H2, Serta 7.300 gerai suku cadang atau H3, yang siap melayani jutaan penggunaan sepeda motor Honda di seluruh Indonesia. (www.astra- 


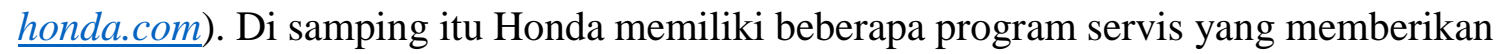
nilai lebih bagi pelanggan, antara lain Honda Experience Card yang merupakan kartu servis eksklusif untuk layanan darurat 24 jam, 30 minutes quick service untuk perbaikan ringan, waktu buka bengkel yang lebih pagi, serta sistem antrian di bengkel yang lebih baik. Semua itu juga didukung oleh Honda Customer Care dan juga tenaga bengkel yang ramah serta profesional. Dari pernyataan Kotler dan Amstrong (2001) bahwa pembelian konsumen secara kuat dipengaruhi oleh karakteristik kosumen yang terdiri dari faktor budaya, faktor sosial, faktor pribadi dan faktor psikologis. Dan selanjutnya perilaku konsumen akan menentukan proses pengambilan keputusan dalam pembelian merek, proses tersebut merupakan sebuah pendekatan penyesuaian masalah yang terdiri dari lima tahap yang dilakukan konsumen, kelima tahap tersebut adalah kebutuhan dan pengenalan, pencarian informasi, evaluasi alternatif, pembelian dan perilaku pasca pembelian (Charles, Joseph dan Carl, 2001). Consumers often use extrinsic cues, such as price or brand, to infer product quality (Rao, Akshay R. dan Monroe, Kent B., 1989), citra merk dari berbagai produk honda sangat familiar di masyarakat yang merupakan output dari dampak kualitas produk dan pemberian berbagai layanan kepada setiap pelanggan, citra merk terbentuk secara alamiah dari kaidah empiris konsumen yang mengalami atau sedang menggunakan produk dan layanan dari perusahaan tersebut. Dengan citra merk yang positif konsumen tidak perlu ragu dan bingung dalam menentukan produk yang akan dibeli serta digunakan, Consumers use brand to make the decision process simpler and more efficient (Lester W. Johnson, Geoffrey N. Soutar and Jillian C. Sweeney, 2000). Berdasarkan dari data yang dirilis Asosiasi Industri Sepeda Motor Indonesia (AISI) yang tercantum pada tabel 1 sebagai berikut:

Tabel 1. Data Penjualan Sepeda Motor Periode Januari-Maret 2018

\begin{tabular}{|c|l|c|}
\hline No. & \multicolumn{1}{|c|}{ Nama Merek } & Volume Penjualan \\
\hline \multirow{2}{*}{1.} & Honda & 1.069 juta unit \\
\hline \multirow{2}{*}{} & Beat series & 420.117 unit \\
\cline { 2 - 3 } & Scoopy & 198.566 unit \\
\cline { 2 - 3 } & All New Vario 125 & 157.936 unit \\
\cline { 2 - 3 } & Vario 150 & 93.948 unit \\
\cline { 2 - 3 } & Revo & 36.112 unit \\
\cline { 2 - 3 } & Supra X 125 & 27.354 unit \\
\hline \multirow{2}{*}{2.} & Yamaha & 341.544 unit \\
\hline \multirow{3}{*}{} & Nmax & 103.411 unit \\
\cline { 2 - 3 } & Mio M3 & 75.010 unit \\
\cline { 2 - 3 } & Aerox 155 & 40.183 unit \\
\cline { 2 - 3 } & Fino & 34.938 unit \\
\hline 3. & Kawasaki & 31.934 unit \\
\hline 4. & Suzuki & 14.628 unit \\
\hline 5. & TVS & 92 unit \\
\hline
\end{tabular}

Sumber: AISI (Asosiasi Industri Sepeda Motor Indonesia) 2018 
Akan tetapi berbanding terbalik dengan kondisi penjualan sepeda motor Honda All New Vario 125 di Kota Tasikmalaya yang mengalami masa sulit. Dimana PT. Niaga Redja Abadi yang merupakan salah satu dealer resmi motor Honda pada bulan september 2018 mengalami penurunan volume penjualan yang signifikan untuk produk All New Vario 125. Dari target terbanyak 600 unit/bulan secara keseluruhan, PT. Niaga Redja Abadi hanya mampu menjual 200 unit dalam satu bulan terakhir, dari fenomena tersebut membuktikan terdapat gejala yang tidak wajar terkait perspektif dan kepercayaan masyarakat terhadap produk merek Honda.

\section{Literature Review}

\subsection{Kualitas Produk}

Berbicara mengenai produk maka aspek yang perlu diperhatikan adalah kualitas produk, definisi kualitas sendiri memiliki pusat dari ruang lingkup konsumen sehingga dapat dikatakan bahwa seorang penjual telah memberikan kualitas bila produk atau pelayanan penjual telah memenuhi atau melebihi harapan konsumen. Kotler (2007) menjelaskan kualitas produk merupakan ciri dan karkettrristik suatu barang atau jasa yang berpengaruh pada kemampuannya untuk memuaskan kebutuhan yang dinyatakan atau tersirat. Dilanjutkan Simamora (2001), menyebutkan kualitas produk merupakan selisih produk yang layak menurut konsumen dengan produk menurut konsumen saat ini. Produk yang berkualitas tinggi sangat diperlukan agar kebutuhan dan keinginan konsumen dapat dipenuhi.

\subsection{Layanan Purnajual}

Layanan purna jual merupakan bagian yang penting dari kegiatan pemasaran produk. Pihak konsumen menuntut pula bagaimana layanan purna jual dari produk yang dibelinya. Kotler dan Keller (2005) menyatakan layanan purna jual kegiatan untuk memberikan dukungan terbaik, perusahaan memberikan layanan purna jual, sebagian besar perusahaan bergerak melalui beberapa tahap. Penjelasan Barata (2003) mengenai pelayanan purna jual merupakan tanggung jawab penjual atas kualitas barang yang dijualnya yang dapat diberikan dalam bentuk konsultasi lanjutan, atau garansi berupa penggantian barang rusak, pemeliharaan, penyediaan suku cadang dan sebagainya.

\subsection{Citra Merek}

Keterkaitan konsumen pada suatu merek akan lebih kuat apabila dilandasi pada banyak pengalaman atau penampakkan untuk mengkomunikasikannya sehingga akan terbentuk citra merek (brand image). Freddy Rangkuty (2002) berpendapat bahwa citra merek merupakan sekumpulan asosiasi merek yang terbentuk dibenak konsumen. Sedangkan Kotler (2009) menjelaskan citra merek sebagai persepsi dan keyakinan yang dilakukan oleh konsumen, seperti tercermin dalam asosiasi yang terjhadi dalam memori konsumen. Konsumen yang terbiasa menggunakan merek tertentu akan cenderung memiliki konsistensi terhadap citra merek tersebut.

\subsection{Proses Keputusan Pembelian}

Masyarakat terutama konsumen pada era globalisasi sangat selektif dalam melakukan pembelian terhadap produk, maka produsen harus dapat mengoptimalkan produk yang dihasilkannya agar tercapainya kepuasan yang diharapkan oleh konsumen. Menurut 
Kotler dan Amstrong (2001) mengemukakan bahwa keputusan pembelian adalah tahap proses pengambilan keputusan membeli dimana konsumen benar-benar membeli produk. Kemudian Swasta dan Handoko (2008), menyatakan keputusan pembelian merupakan sebuah pendekatan penyelesaian masalah pada kegiatan manusia untuk membeli suatu barang atau jasa dalam memenuhi keinginan dan kebutuhannya yang terdiri dari pengenalan kebutuhan dan keinginan, pencarian informasi, evaluasi terhadap alternatif pembelian, keputusan pembelian dan tingkah laku setelah pembelian.

\section{Metodologi Penelitian}

Lebih jelasnya metode penelitian survei dipakai untuk mengetahui adanya hubungan antara kualitas produk dan layanan purna jual kepada citra merek, dan pada proses keputusan pembelian. Penetapan objek penelitian ditunjukkan pada konsumen Dealer Niaga Redja Abadi Kota Tasikmalaya, dimana konsumen tersebut sudah menggunakan produk motor Honda All New Vario 125 dan merasakan layanan purna jual yang diberikan unit showroom dealer tersebut. Populasi yang dijadikan responden penelitian berjumlah 170 orang periode 2014-2018, dengan menggunakan teknik simple random sampling dan rumus slovin sampel yang ditetapkan selanjutnya berjumlah 119 orang. Penggunaan teknik analisis data dengan menggunakan path analysis, dalam analisis jalur ini dapat dilihat pengaruh dari setiap variabel secara bersama - sama. Selain itu juga, tujuan dilakukannya analisa jalur untuk menerangkan pengaruh langsung atau tidak langsung dari beberapa variabel penyebab terhadap variabel lainnya. Selanjutnya ditunjang melalui perhitungan sobel test agar dapat mengetahui hubungan antara variabel intervening/ perantara dengan variabel independen.

\section{Hasil dan Pembahasan}

Adapun hasil perhitungan pengaruh Kualitas Produk Dan Layanan Purnajual Secara Parsial dan Simultan Terhadap Citra Merek Honda All New Vario 125.

Gambar 1. Hubungan Struktural Kualitas Produk dan Layanan Purnajual Terhadap Citra Merek

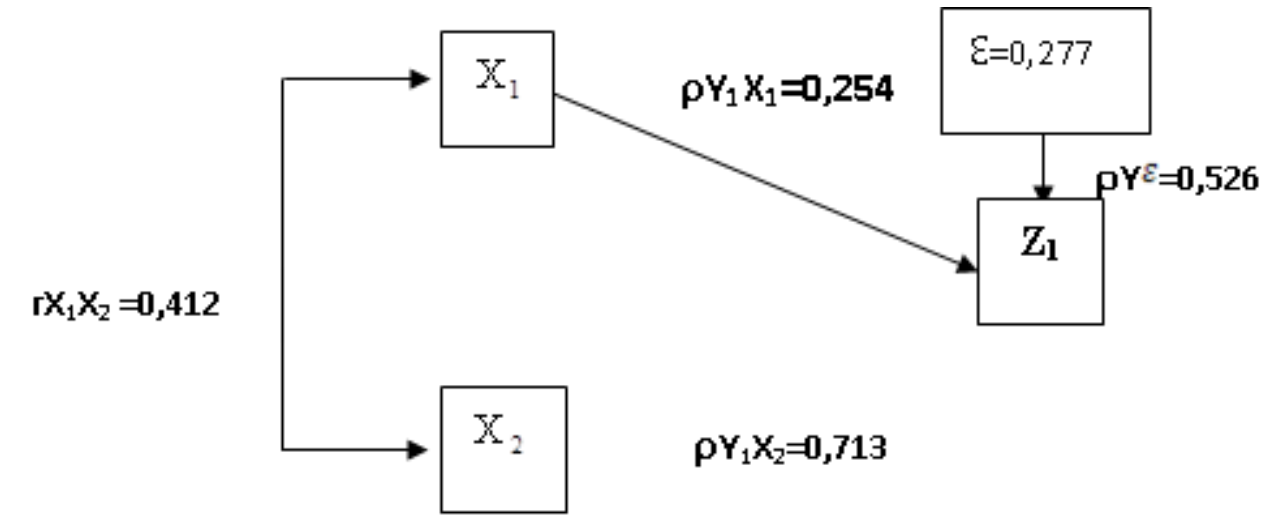

Gambar 1 menunjukkan nilai koefisien jalur kualitas produk $\left(\mathrm{X}_{1}\right)$ terhadap citra merek $\left(\mathrm{Z}_{1}\right)$ sebesar 0,254 , nilai koefisien jalur variabel layanan purnajual $\left(\mathrm{X}_{2}\right)$ terhadap citra merek $\left(Z_{1}\right)$ sebesar 0,713 dan nilai korelasi antara kualitas produk $\left(X_{1}\right)$ dengan layanan purnajual $\left(\mathrm{X}_{2}\right)$ sebesar 0,412 . Sedangkan nilai koefisien determinasi sebesar 0,723 , sehingga diperoleh besar nilai koefisien non determinasi sebesar 0,277 dan koefisien 
residu $\rho Y^{\varepsilon}=\sqrt{1-0,723}=0,526$. Hal tersebut menunjukkan masih terdapat faktor-faktor yang mempengaruhi citra merek selain kualitas produk dan layanan purnajual. Kemudian tahapan selanjutnya mencari pengaruh proporsional setiap variabel independen terhadap variabel dependen, rinciannya adalah sebagai berikut:

Tabel 2. Pengaruh Langsung dan Tidak Langsung Kualitas Produk dan Layanan Purna

\begin{tabular}{|c|c|c|c|}
\hline No & Nama Variabel & \multicolumn{2}{|l|}{ Formula } \\
\hline \multirow[t]{4}{*}{1.} & \multicolumn{3}{|l|}{ Kualitas Produk } \\
\hline & a. Pengaruh Langsung $\mathrm{X}_{1}$ Tehadap $\mathrm{Y}_{1}$ & $\left(\rho Y_{1} X_{1}\right)\left(\rho Y_{1} X_{1}\right)$ & 0,064 \\
\hline & $\begin{array}{l}\text { b. Pengaruh Tidak Langsung } X_{1} \text { Melalui } \\
X_{2}\end{array}$ & $\left(\rho Y_{1} X_{1}\right)\left(r X_{1} X_{2}\right)\left(\rho Y_{1} X_{2}\right)$ & 0,075 \\
\hline & Pengaruh X1 Total Terhadap $Y_{1}$ & $a+b \ldots . . .(1)$ & $\mathbf{0 , 1 3 9}$ \\
\hline \multirow[t]{6}{*}{2.} & \multicolumn{3}{|l|}{ Layanan Purnajual } \\
\hline & c. Pengaruh Langsung $\mathrm{X}_{2}$ Tehadap $\mathrm{Y}_{1}$ & $\left(\rho Y_{1} X_{2}\right)\left(\rho Y_{1} X_{2}\right)$ & 0,508 \\
\hline & $\begin{array}{l}\text { d. Pengaruh Tidak Langsung } X_{2} \text { Melalui } \\
X_{1}\end{array}$ & $\begin{array}{l}\left(\rho Y_{1} X_{2}\right)( \\
\left.r X_{1} X_{2}\right)\left(\rho Y_{1} X_{1}\right)\end{array}$ & 0,075 \\
\hline & Pengaruh X2 Total Terhadap $\mathrm{Y}_{1}$ & $c+d \ldots . . . .(2)$ & $\mathbf{0 , 5 8 3}$ \\
\hline & Total Pengaruh $\mathrm{X}_{1} \& \mathrm{X}_{2}$ terhadap $\mathrm{Y}_{1}$ & $(1)+(2)=k d$ & $\mathbf{0 , 7 2 3}$ \\
\hline & Pengaruh lain yang tidak diteliti & 1-kd=knd & 0,277 \\
\hline
\end{tabular}

Kualitas produk dan layanan purnajual mempengaruhi secara langsung pada citra merek sebesar $6,4 \%$, dan $50,8 \%$, sedangkan kualitas produk dan layanan purnajual berpengaruh secara tidak langsung terhadap citra merek diperoleh sebesar 7,5\% dan 7,5\%. Dengan demikian secara total kualitas produk dan layanan purnajual akan dapat mempengaruhi citra merek sebesar 13,9\% dan 58,3\%. Berdasarkan hasil perhitungan tersebut maka semakin baik kualitas produk Honda All New Vario 125 dan kualitas layanan purnajual yang diberikan gerai service Honda maka citra merek akan semakin meningkat. Nilai koefisien determinasi yaitu $0,139+0,583=0,723$, dari hasil tersebut membuktikan bahwa pengaruh kualitas produk dan layanan purnajual terhadap citra merek secara simultan atau bersama-sama sebesar $72,3 \%$, sedangkan $27,7 \%$ dipengaruhi oleh variabel lain yang tidak diteliti, sehingga dari perhitungan tersebut diketahui layanan purnajual gerai service ternyata berpengaruh lebih dominan pada citra merek.

Perhitungan $\mathrm{F}_{\text {hitung }}$ dan $\mathrm{F}_{\text {tabel }}$ diperoleh sebesar 151,15 dan 2,68, sehingga interprestasi menujukkan hipotesis nol (Ho) ditolak dan hipotesis alternatif (Ha) diterima. Diterimanya hipotesis alternatif bahwa pada tingkat keyakinan 95\% menunjukkan bahwa kualitas produk dan layanan purnajual secara simultan berpengaruh signifikan terhadap citra merek Honda All New Vario 125. Secara parsial kualitas produk pada citra merek dilakukan melalui kaidah pengujian hipotesis, dan diperoleh thitung sebesar 4,73 dan tabel 1,966. Sehingga $t_{\text {hitung }}>t_{\text {tabel}}$, dengan kata lain kualitas produk secara parsial berpengaruh signifikan terhadap citra merek. Sedangkan layanan purnajual secara parsial pada citra merek, diperoleh $t_{\text {hitung }}$ sebesar 13,29 dan $t_{\text {tabel }}$ 1,966. Sehingga $t_{\text {hitung }}>t_{\text {tabel }}$, sehingga 


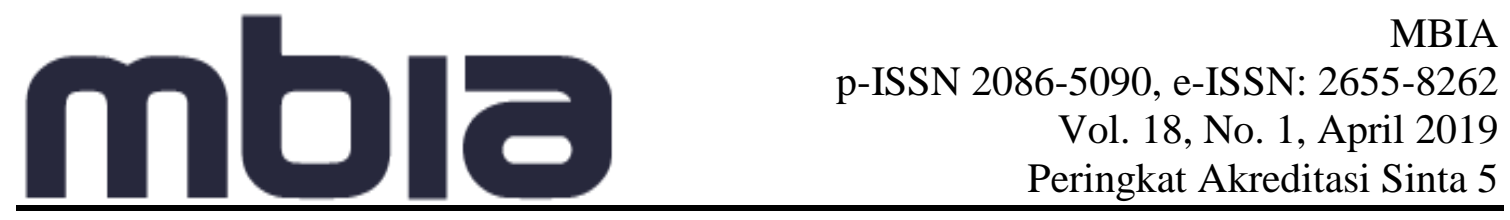

layanan purnajual secara parsial berpengaruh secara signifikan terhadap citra merek motor Honda All Vario New 125.

Besarnya pengaruh kualitas produk $\left(\mathrm{X}_{1}\right)$, dan layanan purnajual $\left(\mathrm{X}_{2}\right)$ terhadap proses keputusan pembelian ( $\left.\mathrm{Y}_{1}\right)$ motor Honda All New Vario 125, dapat dilihat dari indikator yang digunakan masing-masing variabel, dengan menggunakan analisis jalur. Adapun hasil perhitungan analisis jalur dapat dilihat pada diagram jalur pada gambar dibawah ini:

Gambar. Hubungan Struktural antara Variabel Kualitas Produk dan Layanan Purnajual Terhadap Proses Keputusan Pembelian

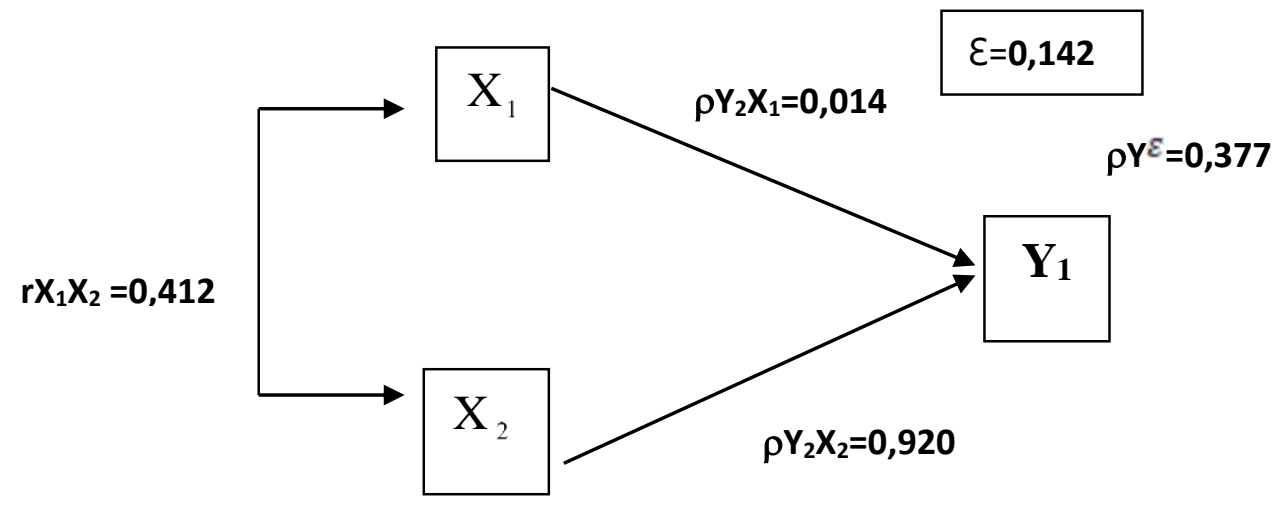

Gambar 2 memperlihatkan nilai koefisien jalur kualitas produk $\left(\mathrm{X}_{1}\right)$ terhadap proses keputusan pembelian $\left(\mathrm{Y}_{1}\right)$ sebesar 0,014 , nilai koefisien jalur layanan purnajual $\left(\mathrm{X}_{2}\right)$ terhadap proses keputusan pembelian $\left(\mathrm{Y}_{1}\right)$ sebesar 0,920 , dan nilai korelasi antara kualitas produk $\left(\mathrm{X}_{1}\right)$ dengan layanan purnajual $\left(\mathrm{X}_{2}\right)$ sebesar 0,412. Dilanjutkan nilai koefisien determinasi sebesar 0,858, sehingga diperoleh besar nilai koefisien non determinasi sebesar 0,142 dan koefisien residu $\rho Y^{\varepsilon}=\sqrt{1-0,858}=0,377$. Hal tersebut menjelaskan masih terdapat faktor-faktor yang dapat mempengaruhi proses keputusan pembelian selain kualitas produk dan layanan purnajual. Kemudian langkah yang digunakan dalam mencari pengaruh proporsional setiap variabel independen terhadap variabel dependen, rinciannya adalah sebagai berikut: 
Tabel 3. Pengaruh Langsung dan Tidak Langsung Kualitas Produk dan Layanan Purnajual Terhadap Proses Keputusan Pembelian

\begin{tabular}{|c|c|c|c|}
\hline No. & Nama Variabel & \multicolumn{2}{|l|}{ Formula } \\
\hline \multirow[t]{4}{*}{1.} & \multicolumn{3}{|l|}{ Kualitas Produk } \\
\hline & a. Pengaruh Langsung $\mathrm{X}_{1}$ Tehadap $\mathrm{Y}_{2}$ & $\left(\rho Y_{2} X_{1}\right)\left(\rho Y_{2} X_{1}\right)$ & 0,0002 \\
\hline & $\begin{array}{l}\text { b. Pengaruh Tidak Langsung } X_{1} \text { Melalui } \\
X_{2}\end{array}$ & $\left(\rho Y_{2} X_{1}\right)\left(r X_{1} X_{2}\right)\left(\rho Y_{2} X_{2}\right)$ & 0,0053 \\
\hline & Pengaruh X1 Total Terhadap $\mathrm{Y}_{2}$ & $a+b \ldots . . .(1)$ & 0,0055 \\
\hline \multirow[t]{6}{*}{2.} & \multicolumn{3}{|l|}{ Layanan Purnajual } \\
\hline & c. Pengaruh Langsung $\mathrm{X}_{2}$ Tehadap $\mathrm{Y}_{2}$ & $\left(\rho Y_{2} X_{2}\right)\left(\rho Y_{2} X_{2}\right)$ & 0,85 \\
\hline & $\begin{array}{l}\text { d. Pengaruh Tidak Langsung } X_{2} \text { Melalui } \\
X_{1}\end{array}$ & $\left(\rho Y_{2} X_{2}\right)\left(r X_{1} X_{2}\right)\left(\rho Y_{2} X_{1}\right)$ & 0,0053 \\
\hline & Pengaruh X2 Total Terhadap $Y_{2}$ & $c+d \ldots . . . . .(2)$ & $\mathbf{0 , 8 5 5}$ \\
\hline & Total Pengaruh $X_{1 \&} X_{2}$ terhadap $Y_{2}$ & $(1)+(2)=\mathrm{kd}$ & $\mathbf{0 , 8 5 8}$ \\
\hline & Pengaruh lain yang tidak diteliti & $1-\mathrm{kd}=\mathrm{knd}$ & 0,142 \\
\hline
\end{tabular}

Kualitas produk mempengaruhi secara langsung proses keputusan pembelian sebesar $0,02 \%$, sedangkan pengaruh kualitas produk terhadap proses keputusan pembelian melalui hubungannya dengan layanan purnajual sebesar $0,53 \%$, dengan demikian secara total kualitas produk akan dapat mempengaruhi citra merek sebesar 0,55\%. Artinya, semakin baik kualitas produk motor Honda All New Vario 125 maka proses keputusan pembelian konsumen terhadap produk Honda akan semakin meningkat. Layanan purnajual secara langsung dapat berpengaruh pada proses keputusan pembelian sebesar $85 \%$, sedangkan pengaruh layanan purnajual terhadap proses keputusan pembelian melalui hubungannya dengan kualitas produk sebesar 0,53\%, dengan demikian secara total layanan purnajual akan dapat mempengaruhi proses keputusan pembelian sebesar $85,5 \%$. Artinya, semakin baik layanan purnajual gerai service motor Honda maka proses keputusan pembelian konsumen pada produk Honda akan semakin meningkat.

Total pengaruh secara proporsional kualitas produk dan layanan purnajual terhadap proses keputusan pembelian sama dengan nilai koefisien determinasi $\left(\mathrm{R}^{2}\right)$ pada tabel model summary output SPSS (terlampir) atau dapat dilihat pada Tabel 2 nilai koefisien determinasi yaitu $0,0055+0,855=0,858$, Sehingga dapat diketahui bahwa pengaruh kualitas produk dan layanan purnajual terhadap proses keputusan pembelian secara simultan atau bersama-sama adalah sebesar 85,8\%, sedangkan $14,2 \%$ dipengaruhi oleh variabel lain yang tidak diteliti. Dapat dijelaskan secara lebih explisit bahwa layanan purnajual berpengaruh lebih dominan pada proses keputusan pembelian. Oleh karena itu, masih perlu adanya revitalisasi dalam kualitas produk motor Honda agar proses keputusan pembelian konsumen akan lebih meningkat. Selain itu 14,2\% proses keputusan pembelian dipengaruhi oleh variabel lain selain kualitas produk dan layanan purnajual yang tidak diteliti.

Dari hasil perhitungan diperoleh $F_{\text {hitung }}$ dan Ftabel sebesar 351,53 dan 2,68, dengan demikian hipotesis nol (Ho) ditolak dan hipotesis alternatif (Ha) diterima, diterimanya 
hipotesis alternatif bahwa pada tingkat keyakinan 95\% menunjukkan bahwa kualitas produk dan layanan purnajual secara simultan berpengaruh signifikan terhadap proses keputusan pembelian konsumen Honda All New Vario 125. Pengujian secara parsial antara kualitas produk terhadap proses keputusan pembelian dapat dilihat dari hasil perhitungan SPSS versi 23.0 dihasilkan thitung sebesar 0,376 dengan nilai tabel 1,966. Sehingga $t_{\text {hitung }}>t_{\text {tabel }}$, diinterprestasikan kualitas produk secara parsial berpengaruh signifikan terhadap proses keputusan pembelian Honda New Vario 125.

Pengujian secara parsial antara layanan purnajual terhadap proses keputusan pembelian dapat dilihat dari perhitungan SPSS versi 23.0, diperoleh thitung sebesar 23,997 dan nilai $t_{\text {tabel }}$ 1,966. Sehingga $t_{\text {hitung }}>t_{t a b e l}$, dengan kata lain layanan purnajual secara parsial berpengaruh secara signifikan terhadap proses keputusan pembelian Honda All New Vario 125. Sedangkan untuk mengetahui pengaruh citra merek terhadap proses keputusan pembelian motor Honda All New Vario 125, maka dilakukan uji statistic koefisien jalur. Koefisien jalur ini akan menentukan tingkat keeratan pengaruh antar variabel citra merek dengan proses keputusan pembelian.

Gambar 3. Hubungan Struktural $Z_{1}$ dengan $Y_{1}$

\section{$\varepsilon=0,941$}

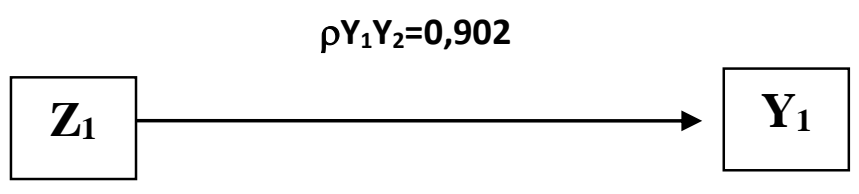

Hasil analisis dengan menggunakan SPSS versi 23.0 menunjukkan koefisien jalur hubungan citra merek pada proses keputusan pembelian sebesar 0,902, artinya besarnya citra merek berpengaruh terhadap proses keputusan pembelian. Adapun untuk melihat apakah pengaruh tersebut signifikan atau tidak maka dilakukan perbandingan nilai thitung sebesar 22,587. Dengan $t_{\text {tabel }}$ sebesar 1,98 sehingga Ho ditolak dan menunjukkan bahwa citra merek berpengaruh signifikan terhadap proses keputusan pembelian motor Honda All New Vario 125.

Sobel test digunakan dalam menguji signifikansi pengaruh tidak langsung dengan menghitung nilai $t$ dari koefisien $a b$. Nilai $t_{\text {hitung }}$ akan dibandingkan dengan $t_{\text {tabel }}$ dan jika $t_{\text {hitung }}>$ dari nilai $t_{\text {table }}$ maka dapat disimpulkan bahwa terjadi pengaruh mediasi. Berikut ini hasil perhitungan sobel test:

Tabel 3. Sobel Test

\begin{tabular}{|l|c|c|c|c|c|c|c|}
\hline & $\mathbf{A}$ & $\mathbf{B}$ & $\mathbf{S a}$ & $\mathbf{S b}$ & $\mathbf{a b}$ & $\mathbf{S a b}$ & $\mathbf{T}$ \\
\hline $\mathrm{X}_{1}$ & 0,254 & \multirow{2}{*}{0,902} & 0,071 & \multirow{2}{*}{0,041} & 0,229 & 0,0648 & 3,53 \\
\cline { 1 - 1 } \cline { 6 - 8 } & & 0,107 & & 0,643 & 0,1005 & 6,39 \\
\hline
\end{tabular}

Sumber: Data Yang Diolah

Pengujian pengaruh mediasi antara kualitas produk terhadap proses keputusan pembelian melalui citra merek dapat dilihat melalui perolehan $t_{\text {hitung }}$ sebesar 3,53 dan nilai $t_{\text {tabel }} 1,98$. 
Sehingga $t_{\text {hitung }}>t_{\text {tabel}}$, diinterprestasikan bahwa kualitas produk berpengaruh signifikan terhadap proses keputusan pembelian melalui citra merek. Sedangkan pengujian pengaruh mediasi antara layanan purnajual terhadap proses keputusan pembelian melalui

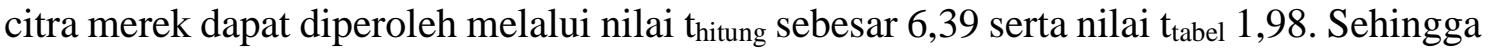
$t_{\text {hitung }}>t_{\text {tabel }}$, dengan kata lain layanan purnajual berpengaruh signifikan terhadap proses keputusan pembelian melalui citra merek.

Hasil penelitian menujukkan bahwa kualitas produk berpengaruh signifikan terhadap proses keputusan pembelian melalui citra merek, penjelasan tersebut mengindikasikan produk Motor Honda All New Vario 125 memiliki spesifikasi yang lengkap, performa yang tangguh dan fitur yang menarik sehingga memberikan citra positif kepada pelanggan. Menurut Kotler (2005) kualitas merupakan bentuk penilaian atas produk yang akan dibeli, apakah sudah memenuhi apa yang diharapkan konsumen. Selain itu menurut (Simamora, 2001) adanya kualitas produk yang baik maka konsumen dengan mudah dapat membeli barang yang diinginkan. Produk yang diinginkan konsumen adalah produk yang berkualitas, semakin berkualitas suatu produk, maka semakin tinggi keputusan konsumen untuk melakukan pembelian. Dari pernyataan tersebut dapat dibuktikan dengan penelitian yang dilakukan Endang Tjahjaningsih dan Maurine Yuliani (2009) dimana kualitas produk berpengaruh signifikan terhadap keputusan pembelian dan kualitas produk memiliki pengaruh positif pada keputusan pembelian. Timbulnya persepsi positif dari para konsumen akan membentuk citra yang baik terhadap produk motor Honda All New Vario 125. Persepsi dapat diartikan sebagai sebuah proses yang digunakan individu untuk memilih, mengorganisasi, dan menginterpretasi masukan informasi guna menciptakan sebuah gambaran, gambaran tersebut yang kemudian disebut dengan citra (Kotler, 2003). Sehingga dari kelebihan yang dimiliki produk Honda All New Vario 125 menimbulkan adanya dampak positif yang mengarah kepada proses keputusan pembelian konsumen. Selain itu layanan purnajual berpengaruh signifikan terhadap proses keputusan pembelian melalui citra merek, dapat dijelaskan bahwa layanan purnajual merupakan gambaran dari core service dan deliver service yang dalam hal ini pemberian layanan purnajual kepada konsumen memberikan bahan pertimbangan dalam proses keputusan pembelian suatu produk. Dari hasil observasi lapangan oleh penulis dan melakukan wawancara dengan para responden adanya layanan purnajual yang diberikan setiap gerai resmi Honda dengan menyediakan layanan bebas panggilan yang menjadi solusi alternatif bagi konsumen yang mempunyai kendala jarak yang cukup jauh dan waktu yang tidak memungkinkan untuk melakukan service motor dengan datang langsung ke gerai Honda. Pelayanan tersebut membentuk adanya citra yang positif dari pandangan konsumen yang implikasinya dapat berpengaruh terhadap proses keputusan pembelian, hal ini diperkuat bahwasannya keputusan pembelian seorang konsumen untuk menggunakan produk merupakan suatu proses yang komplek dan dipengaruhi oleh berbagai faktor seperti keputusan tentang produk, keputusan tentang merek, keputusan tentang waktu, keputusan tentang penjual, keputusan tentang jumlah, keputusan tentang harga, keputusan tentang layanan yang diberikan perusahaan Basu Swastha (2002).

\section{Simpulan}

Dari hasil penelitian yang telah dibuktikan terkait dengan kualitas produk dan layanan purna jual berpengaruh secara signifikan terhadap citra merek baik secara parsial dan simultan, produk motor Honda memiliki kualitas sempurna bagi ekspektasi konsumen, 


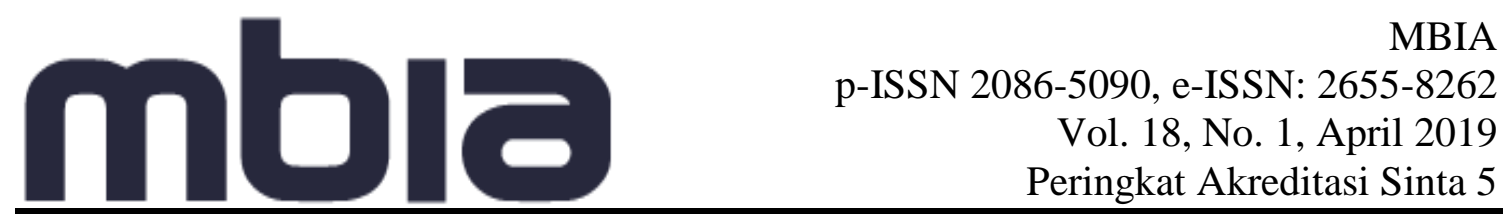

terutama motor Honda All New Vario 125 dengan fitur yang canggih serta desain yang lebih varian. Perusahaan Honda selalu berusaha memuaskan konsumen mereka dengan menawarkan produk berkualitas, produk yang berkualitas dapat dikatakan produk yang memiliki manfaat bagi pemakainya (konsumen). Seseorang yang membutuhkan suatu produk akan membayangkan manfaat apa saja yang bisa diperoleh dari produk yang akan dipergunakan. Manfaat dari produk Honda merupakan konsekuensi yang diharapkan konsumen ketika membeli dan menggunakan suatu produk. Oleh karena itu Honda berusaha memfokuskan pada kualitas produk dan layanan untuk membandingkannya dengan produk yang ditawarkan oleh perusahaan pesaing. Akan tetapi, suatu produk dengan penampilan terbaik atau bahkan dengan tampilan lebih baik bukanlah merupakan produk dengan kualitas tertinggi jika tampilannya bukanlah yang dibutuhkan dan diinginkan oleh pasar. Konsumen mempunyai pengetahuan declarative terkait produk kendaraan roda dua yang dipasarkan oleh Honda dan mempercayai akan kualitasnya. Selain itu layanan purnajual dari gerai Honda memberikan kepedulian, sehingga membentuk kepercayaan kepada perusahaan otomotif tersebut, kepercayaan konsumen akan kualitas produk Honda All New Vario 125 dan layanan purnajual menciptakan citra merek positif dari konsekuensi komitmen Honda.

\section{Daftar Pustaka}

Atep Adya Barata. (2003). Dasar- Dasar Pelayanan Prima. Jakarta: Elex Media. Kompetindo

Archer, N. P., \& Wesolowsky, G. O. (1996). Consumer response to service and product quality: A study of motor vehicle owners. Journal of Operations Management, 14(2), 103-118. https://doi.org/10.1016/0272-6963(95)00045-3

Armstrong, Gery dan Kotler, Philip. (2001). Prinsip-Prinsip Pemasaran. Jilid 1. Edisi Kedelapan. Jakarta: Erlangga

Basu Swastha. (2002). Manajemen Pemasaran Edisi Kedua. Cetakan Kedelapan. Jakarta: Penerbit Liberty

Basu Swasta dan T. Hani Handoko. (2008). Manajemen Pemasaran, Analisa. Perilaku Konsumen, Edisi pertama, Cetakan keempat. Yogyakarta: BPFE

Bilson, Simamora. (2001). Memenangkan Pasar dengan Pemasaran Efektif dan Profitabel. Edisi pertama. Jakarta: PT. Gramedia Pustaka Utama

Bijvank, M., Koole, G., Vis, I.F.A. (2010). Optimising a general repair kit problem with a service constraint. European Journal of Operational Research, 204(1), pp. 76-85.

Charles W. Lamb, Joseph F. Hair, Carl Mcdaniel., (2001), Pemasaran. Edisi Pertama, Jakarta: Salemba Empat

Davies, A. (2004). Moving base into high-value integrated solutions: A value stream approach. Industrial and Corporate Change, 13(5), pp. 727-756.

Johnson, L. W., Soutar, G. N., \& Sweeney, J. C. (2000). Moderators of the brand image/perceived product quality relationship. Journal of Brand Management, 7(6), 425-433. https://doi.org/10.1057/bm.2000.34

Julian, C.C., \& Ramaseshan, B. (1994). The role of customer-contact personnel in the marketing of a retail bank's services. International Journal of Retail and Distribution Management, 22(5), pp. 29-34.

Kotler, Amstrong. (2001). Prinsip-prinsip pemasaran, Edisi keduabelas, Jilid 1. Jakarta: Erlangga

Kotler, P. (2003). Marketing Management, 11th Edition.Prentice Hall.Inc.New Jersey 


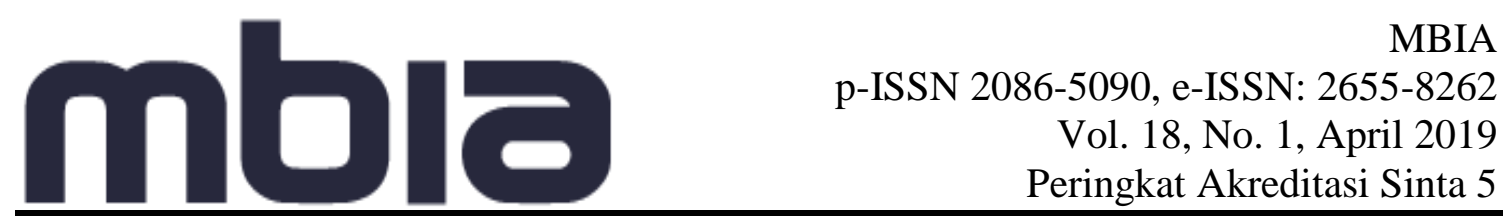

Kotler, P. (2005). Manajemen Pemasaran. Jilid 1 dan 2. Jakarta: PT Indeks. Kelompok Gramedia.

Kotler, P. (2007). Manajemen Pemasaran. Edisi kesebelas Jilid 1. Jakarta: PT. Indeks

Kotler, P. (2009). Manajemen Pemasaran, Edisi 13. Jakarta: Erlangga.

Kotler, P., \& Keller, K.L. (2012). Manajemen Pemasaran Edisi 12. Jakarta: Erlangga

Nurudin, A. (2013). https://otomotif.bisnis.com (diakses pada tanggal 7 Maret 2018)

Penttinen, E., \& Palmer, J. (2007). Improving firm positioning through enhanced offerings and buyer-seller relationships. Industrial Marketing Management, 36(5), 552-564.

Rangkuti, F. (2002). Measuring Customer Satisfaction. Jakarta: PT. Gramedia Pustaka Utama

Rao, Akshay R., \& Monroe, Kent B. (1989). The Effect of Price, Brand Name and Store Name on Buyers' Perceptions of Product Quality. Journal of Marketing Research, 26, pp. 351-57

Tjahjaningsih, E., \& Yuliani, M. (2009). Analisis Kualitas Produk Dan Citra Merek Dalam Mempengaruhi Keputusan Pembelian Dan Dampaknya Terhadap Loyalitas Merek HP Nokia. Jurnal Telaah Manajemen, 6(2), pp. 104-118.

Zeithaml, V.A. (1996). The behavioral consequences of service quality. Journal of Marketing, 60(2), pp.31-46.

\section{Copyright Disclaimer}

Copyright for this article is retained by the author(s), with first publication rights granted to the journal. 